\begin{tabular}{ll} 
MARLIN & $\begin{array}{l}\text { Marine and Fisheries Science Technology Journal } \\
\text { Tersedia online di: http://ejournal-balitbang.kkp.go.id/index.php/marlin } \\
\text { e-mail:jurnal.marlin@gmail.com } \\
\text { Volume 1 Nomor 1 Februari } 2020 \\
\text { p-ISSN:2716-120X } \\
\text { e-ISSN: 2715-9639 }\end{array}$ \\
\hline
\end{tabular}

\title{
ANALISIS NUMERIK PENGARUH MULTIBODY PADA KONFIGURASI TRANSFER LNG SECARA SIDE-BY-SIDE DENGAN VARIASI JARAK
}

\section{NUMERICAL ANALYSIS OF MULTIBODY EFFECT ON SIDE-BY-SIDE TRANSFER LNG CONFIGURATION WITH DISTANCE VARIATIONS}

\author{
Yuni A. Wibowo*1 dan Anas N. Firdaus ${ }^{1}$ \\ ${ }^{1}$ Departemen Teknologi Kelautan, Politeknik Kelautan dan Perikanan Pangandaran, Jl. Raya Babakan KM. 02 Pangandaran, 46396- \\ Jawa Barat, Indonesia \\ Teregistrasi I tanggal: 20 Desember 2019; Diterima setelah perbaikan tanggal: 04 Februari 2020; \\ Disetujui terbit tanggal: 06 Februari 2020
}

\begin{abstract}
ABSTRAK
Kebutuhan akan energi bersih dalam satu dekade terakhir terus meningkat seiring dengan kesadaran user dan regulator untuk menjaga kelestarian lingkungan, sehingga dibutuhkan berbagai macam upaya untuk mengelola dan memperluas produksinya. Salah satu jenis clean energy yang akhir-akhir ini menyita perhatian industri global adalah Liquefied Natural Gas (LNG). Asia Pasifik memiliki 9,4\% dari cadangan gas dunia, dengan Indonesia menyumbang $1,53 \%$. Kebanyakan cadangan LNG ditemukan pada laut lepas (offshore) dan terisolasi dari infrastruktur daratan. Untuk mengatasi permasalahan tersebut dibutuhkanlah fasilitas struktur bangunan apung, seperti FSRU. FSRU sendiri biasanya ditambatkan pada jetty/dermaga dengan sistem berthing. Dalam mendesain dermaga perlu dipertimbangkan gaya-gaya yang timbul akibat kondisi berthing dengan konfigurasi side-by-side. Konfigurasi ini menciptakan efek multibody dalam perilaku hidrodinamika, sehingga penelitian ini bertujuan mengkaji efek multibody antara FSRU dan LNGC dengan variasi jarak satu sama lain 2, 4, 6 dan $8 \mathrm{~m}$. Gerakan FSRU ditinjau dalam penelitian ini dengan skenario pemodelan tanpa pengaruh dan terpengaruh LNGC. Hal ini penting dilakukan dalam perancangan jettykarena FSRU ditambatkan pada jetty. Berdasarkan simulasi numerik analisis dinamis frequency domain yang dihasilkan, didapatkan bahwa efek multibody terlihat pada model side-by-side. Efek multibody akibat propagasi gelombang dari arah head seas $\left(\mu=180^{\circ}\right)$ tidak menyebabkan dampak signifikan pada variasi jarak, kecuali pada jarak $2 \mathrm{~m}$ akibat fenomena standing wave. Pada gelombang yang berpropagasi arah seperempat haluan $\left(\mu=225^{\circ}\right)$ dan arah samping $\left(\mu=270^{\circ}\right)$ juga terlihat adanya efek multibody pada variasi jarak. Pada model dengan jarak 4 dan $8 \mathrm{~m}$, karakter RAO cenderung lebih rendah atau sama dengan RAO pada model FSRU free floating. Namun pada jarak 2 dan $6 \mathrm{~m}$, karakter RAO lebih tinggi dari dari RAO FSRU free floating. Selain menaikkan dan menurunkan harga RAO gerakan, efek multibody juga menggeser frekuensi natural (?) struktur bangunan apung dengan beda $0.1-0.3 \mathrm{rad} / \mathrm{s}$. Hal ini penting diketahui karena posisi frekuensi natural dapat memicu magnifikasi gerakan jika terjadi resonansi.
\end{abstract}

Kata Kunci: side-by-side, multibody, RAO, frekuensi natural

ABSTRACT

The demand of clean energy in the last decade continues to increase along with the awareness of users and regulators to preserve the environment, so that efforts are needed to manage and expand their production. A type of clean energy that has recently caught the attention of the global industry is Liquefied Natural Gas (LNG). Asia Pacific has 9.4\% of the world's gas reserves, with Indonesia contributing 1.53\%. Most LNG reserves are located in offshore and isolated from land infrastructure. To overcome these problems, floating structures, such as the FSRU, are needed. The FSRU is usually moored to the jetty/dock with the berthing system. In designing the jetty it is necessary to consider the forces that arise due to berthing condition with side-by-side configuration. This configuration create a multibody effect in hydrodynamic behavior, this study aims to examine the multibody effects between FSRU and LNGC with variations in distance 2, 4, 6 and $8 \mathrm{~m}$. The FSRU movement was reviewed in this study with a modeling scenario without the influence and influence of the LNGC. This is important to evaluate in designing the jetty because the FSRU is moored to the jetty. According to the numerical simulation

DOI: $h$ ttp://dx.doi.org/10.15578/marlin.V1.I1.2020.25-37

Korespondensi penulis:

e-mail: yuniariwibowo@ymail.com 
of the dynamic frequency domain analysis, it was found that the multibody effect was found in the side-by-side model. The multibody effect due to wave propagation from the direction of the head seas $\left(\mu=180^{\circ}\right)$ does not cause a significant impact on the variation of the distance, except at a distance of $2 \mathrm{~m}$ due to the standing wave phenomenon. While the waves propagating in the direction of a quarter of the bow $\left(\mu=225^{\circ}\right)$ and the side direction $\left(\mu=270^{\circ}\right)$ a multibody effect is also found in the variation of distance. In models with a distance of 4 and $8 \mathrm{~m}$, the RAO character tends to be lower or equal to RAO in the free floating FSRU model. Therefore at a distance of 2 and $6 \mathrm{~m}$, the RAO character is higher than that of the RAO free floating FSRU. In addition to raising and lowering the $R A O$ price of the movement, the multibody effect also shifts the natural frequency of the floating structure with a difference of $0.1-0.3 \mathrm{rad} / \mathrm{s}$. This is important to investigate because the position of natural frequencies can trigger magnification of the movement in the event of resonance.

Keywords: side-by-side, multibody, RAO, natural frequency

\section{PENDAHULUAN}

Dalam satu dekade terakhir permintaan akan energi bersih (clean energy) terus meningkat seiring dengan kesadaran user(pemakai) dan regulator(pemerintah) untuk menjaga kelestarian lingkungan, sehingga dibutuhkan berbagai macam upaya untuk mengelola dan memperluas produksinya. Salah satu jenis clean energy yang akhirakhir ini menyita perhatian industri global, salah satunya di Asia Pasifik adalah Liquefied Natural Gas (LNG). Asia Pasifik memiliki 9,4\% dari cadangan gas dunia, yang mana Cina memiliki 2,9\%, dan Indonesia memiliki 1,53\% dari cadangan gas dunia, (Gus, 2019). Menurut catatan Kementerian Energi dan Sumber Daya Mineral (ESDM) pada Januari 2018, total cadangan gas bumi di Indonesia mencapai 135,55 triliun standar kaki kubik (TSCF), Siswanto, Djoko 2018. Selain memiliki cadangan gas yang cukup besar, Indonesia juga termasuk dalam peringkat lima besar negara eksportir LNG di dunia, dengan lima teratas konsumen LNG Indonesia berdasarkan pangsa adalah Jepang, Korea, Taiwan, Cina dan AS, (Gus, 2019).

Kebanyakan cadangan LNG ditemukan pada laut lepas (offshore) dan terisolasi dari infrastruktur daratan. Untuk mengatasi permasalahan tersebut dibutuhkanlah fasilitas struktur bangunan apung yang dalam satu dekade ini sedang dikembangkan secara masif oleh para ahli di bidang industri teknologi kelautan, seperti halnya Floating Storage Regasification Unit (FSRU). FSRU merupakan fasilitas terapung yang berfungsi untuk menampung dan memproses LNG dari bentuk gas ke cair dan sebaliknya (proses regasifikasi). FSRU ini ditambatkan pada jetty sebagai $L N G$ receiving terminal. Pada dasarnya pola kerja dari terminal ini adalah sebagai berikut : LNG diangkut oleh $L N G$ Carrier (LNGC) dari ladang gas lepas pantai, kemudian ditambatkan pada FSRU secara side-by-side. FSRU sendiri diikat dengan sistem berthing pada jetty. Muatan LNG dari LNGC ditransfer ke FSRU melalui loading arms yang mampu menahan suhu cryogenic LNG yang mencapai $-160^{\circ} \mathrm{C}$.

Sistem tambat side-by-side mengharuskan LNGC berada secara paralel dengan FSRU dan saling berhimpit satu sama lain dengan jarak aman yang diatur oleh OCIMF, sekitar 2 s.d. 8 meter, (OCIMF, 2008). Sistem ini berakibat pada timbulnya efek multibody pada gerakan struktur apung, dimana gerakan LNGC akan mempengaruhi FSRU dan sebaliknya. Efek multibody ini perlu ditinjau dalam merancang jettyyang mampu menahan gerakan dari kedua struktur bangunan apung.

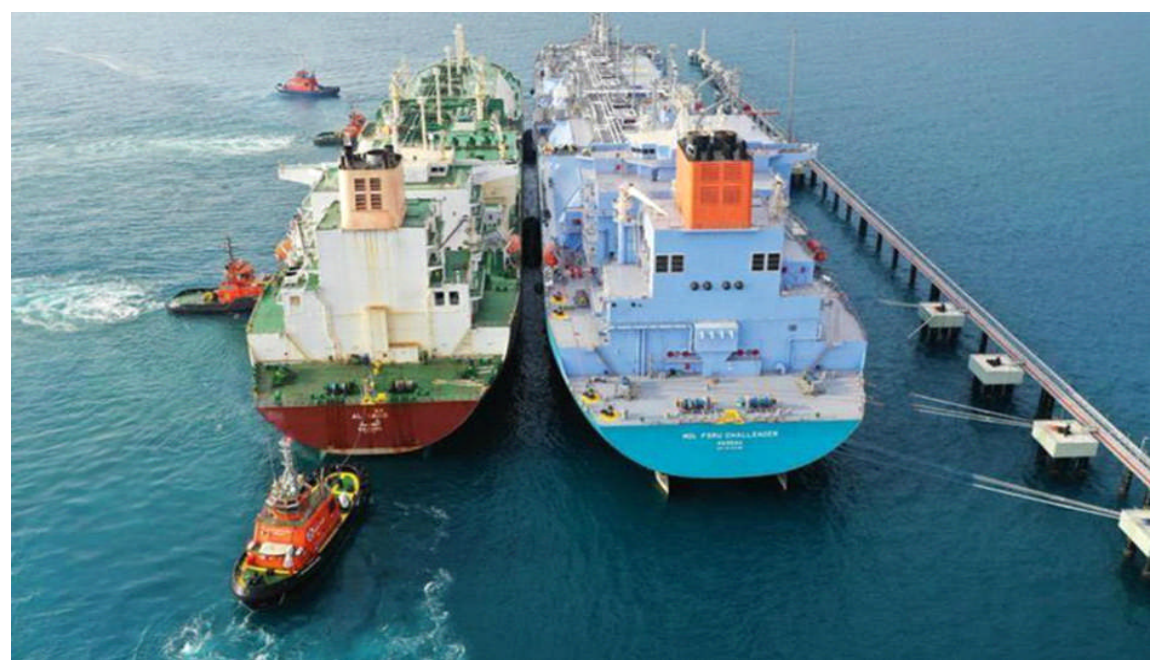

Gambar 1. Konfigurasi side-by-side pada transfer LNG (Sumber : http://mfame.guru/worlds-biggest-ship-to-ship-lngtransfers-starts-off-in-turkey/). 
Kim, (2003) telah meninjau analisis dinamis multibody struktur apung pada FPSO, dia mengidentifikasi pengaruh kopel dengan tali tambat (mooring lines) serta riser pada analisis dinamis. Bunnik, (2009) menganalisis efek damping pada konfigurasi side-by side offloading. Analisis hidrodinamis pada interaksi kedua struktur apung dengan sistem side by side juga telah dilakukan oleh Perwitasari, (2010), Perwitasari meninjau interaksi multibody pada FPSO Sevan Marine yang berbentuk silinder. Kemudian menyusul penelitian dengan pokok bahasan yang sama dan dikembangkan untuk mengetahui operabilitas FSRU saat side by side offloading akibat beban gelombang oleh Ziyan, (2013). Dalam penelitian tersebut baik Perwitasari maupun Ziyan tidak melakukan analisis terhadap pengaruh jarak horisontal yang terbentuk oleh kedua bangunan apung saat side by side offloading. Wibowo, (2014), menganalisis pengaruh jarak pada konfigurasi side-by-side, namun belum memasukkan efek multibody ke dalam analisis dinamis

Penelitian ini bertujuan mengkaji efek multibody antara FSRU dan LNGC yang ditambatkan secara side-by-side dengan variasi jarak satu sama lain 2, 4, 6 dan $8 \mathrm{~m}$. Gerakan FSRU ditinjau dalam penelitian ini dengan skenario pemodelan tanpa pengaruh dan terpengaruh keberadaan LNGC. Hal ini penting dilakukan dalam perancangan jetty karena FSRU ditambatkan pada jetty.

\section{METODOLOGI PENELITIAN Pemodelan}

Dua struktur apung, FSRU dan LNGC dimodelkan sebagai rigid body surface model. Ukuran-ukuran utama (pricipal dimension) struktur apung tersebut dapat dilihat pada Tabel 1. Model tersebut menggunakan pendekatan 3D diffraction yang disusun dari susunan panel method. Pemodelan struktur apung tersebut dilakukan pada pemrograman komputasi difraksi dan dapat dilihat pada Gambar 2. Untuk mendetailkan pemodelan, dilakukan mesh refining membentuk pola meshing kotak agar tekanan pada permukaan model dapat terdistribusikan secara akurat (Gambar 3).

Tabel 1. Ukuran-ukuran utama FSRU dan LNGC

\begin{tabular}{|c|c|c|c|}
\hline VESSEL PARAMETERS & UNIT & FSRU (45.000 CBM) & LNGC (GT : $20.524 \mathrm{~T})$ \\
\hline Length over all (LOA) & $\mathrm{m}$ & 195.30 & 151.00 \\
\hline Length of perpendicular (LPP) & $\mathrm{m}$ & 184.80 & 140.00 \\
\hline Breadth (B) & $\mathrm{m}$ & 30.00 & 28.00 \\
\hline Height $(H)$ & $\mathrm{m}$ & 20.00 & 16.00 \\
\hline $\operatorname{Draft}(T)$ & $\mathrm{m}$ & 9.00 & 7.30 \\
\hline Center of Gravity - X-axis $\left(C O G_{X}\right)$ & $\mathrm{m}$ & 89.48 & 68.98 \\
\hline Center of Gravity - y-axis (COGY) & $\mathrm{m}$ & 0.00 & 0.00 \\
\hline Center of Gravity - z-axis $\left(C^{2} O G_{z}\right)$ & $\mathrm{m}$ & 6.41 & 5.59 \\
\hline Radii of Gyration - x-axis $\left(\boldsymbol{R}_{x x}\right)$ & $\mathrm{m}$ & 10.29 & 9.42 \\
\hline Radii of Gyration - y-axis $\left(\boldsymbol{R}_{y y}\right)$ & $\mathrm{m}$ & 53.35 & 40.41 \\
\hline Radii of Gyration - $z$-axis $\left(\boldsymbol{R}_{z z}\right)$ & $\mathrm{m}$ & 53.35 & 40.41 \\
\hline
\end{tabular}

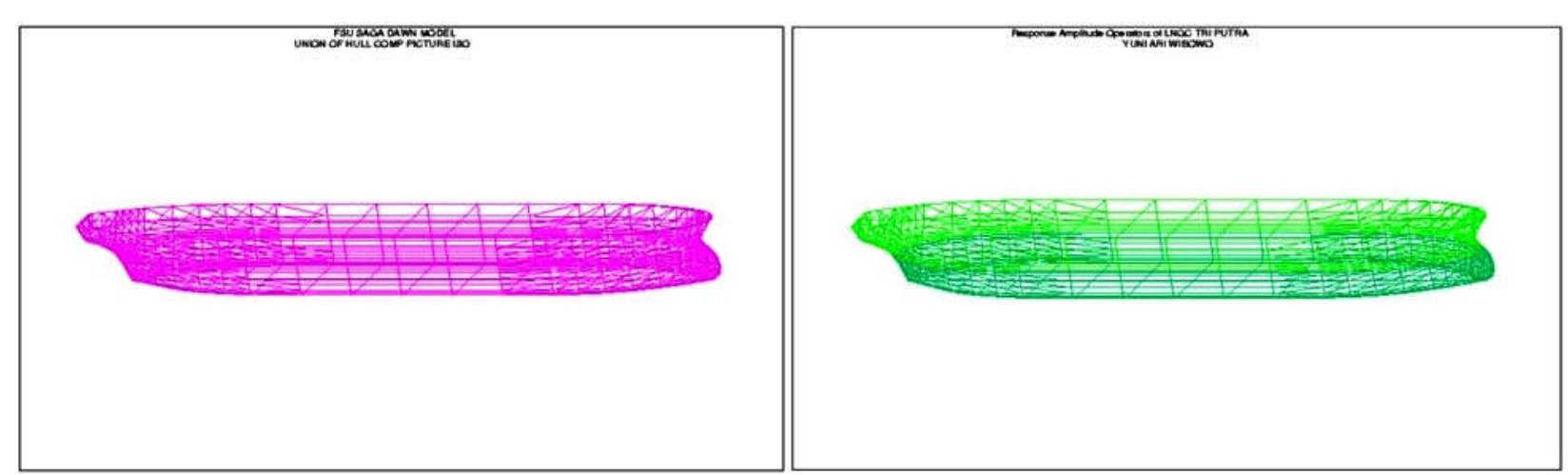

Gambar 2. Pemodelan 3D surface FSRU dan LNGC pada pemrograman komputasi difraksi. 


\section{Konfigurasi Side-by-side}

FSRU dan LNGC dikonfigurasikan secara side-by-side (Gambar 3) dengan variasi jarak 2, 4, 6 dan $8 \mathrm{~m}$ untuk melihat pengaruh multibody pada gerakan struktur apung akibat perbedaan jarak. Simulasi dilakukan dengan 4 model berdasarkan jarak antara FSRU dengan LNGC (Tabel 2).

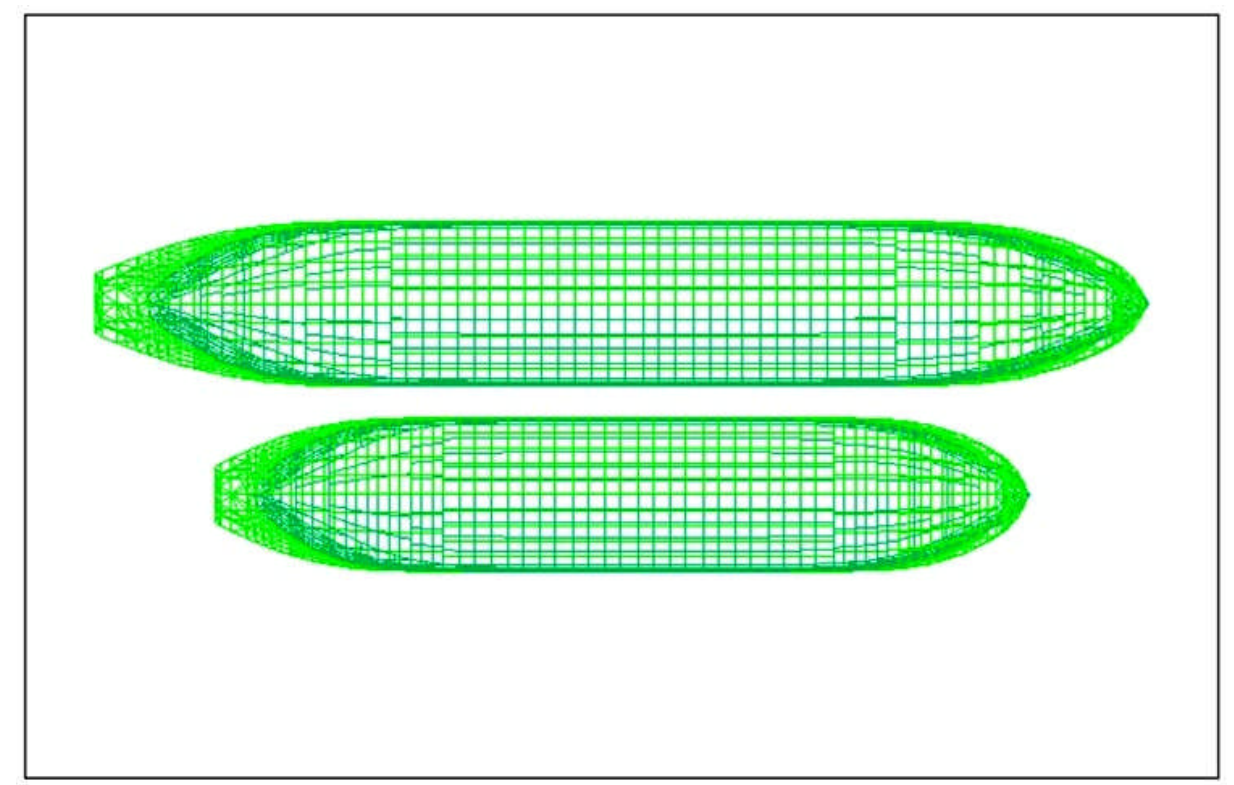

Gambar 3. Konfigurasi side-by-side FSRU dengan LNGC (Atas : FSRU; dan Bawah : LNGC).

Tabel 2. Skenario pemodelan konfigurasi side-by-side berdasarkan jarak antara FSRU dan LNGC

\begin{tabular}{cc}
\hline Konfigurasi Side-by-side & Variasi Jarak antara FSRU dan LNGC (dalam m) \\
\hline Model A & 2 \\
Model B & 4 \\
Model C & 6 \\
Model D & 8 \\
\hline
\end{tabular}

\section{Persamaan Gerak Struktur Apung}

Komponen hidrodinamika yang berperan penting dalam analisis ini mencakup komponen internal dan eksternal. Komponen internal merupakan komponen radiasi yang berasal dari struktur apung, terdiri atas massa struktur apung, massa tambah bagian yang tercelup air (wetted surface), redaman (damping) dan kekakuan (stiffness). Sedangkan komponen eksternal merupakan komponen difraksi dari gaya gelombang linier. Jika komponen tersebut disatukan, maka akan terbentuk persamaan gerak satu derajat kebebasan/Single Degree of Freedom (SDOF) yang dapat dituliskan sebagai persamaan berikut :

$\left[\left(m+m_{a}\right) \ddot{\zeta}+c \dot{\zeta}+k \zeta\right]=F e^{-i w e^{t}}$
dimana;
$m \quad$ : massa struktur apung
$m_{a} \quad$ : massa tambah bagian yang tercelup dari struktur apung
c : redaman
k : kekakuan
$F e^{-i w_{e} t}: \quad$ komponen gaya gelombang linier

Struktur apung memiliki enam derajat kebebasan/Multi Degree of Freedom (MDOF) yang terdiri dari 3 gerakan translasional dan 3 rotasional seperti yang ditunjukkan pada Gambar 4. Sehingga persamaan (1) dapat dituliskan seperti persamaan (2), untuk singlebody.

$\sum_{k=1}^{6}\left[\left(m+m_{a}\right) \ddot{\zeta}+c \dot{\zeta}+k \zeta\right]=F e^{-i w t} e^{t}$ 


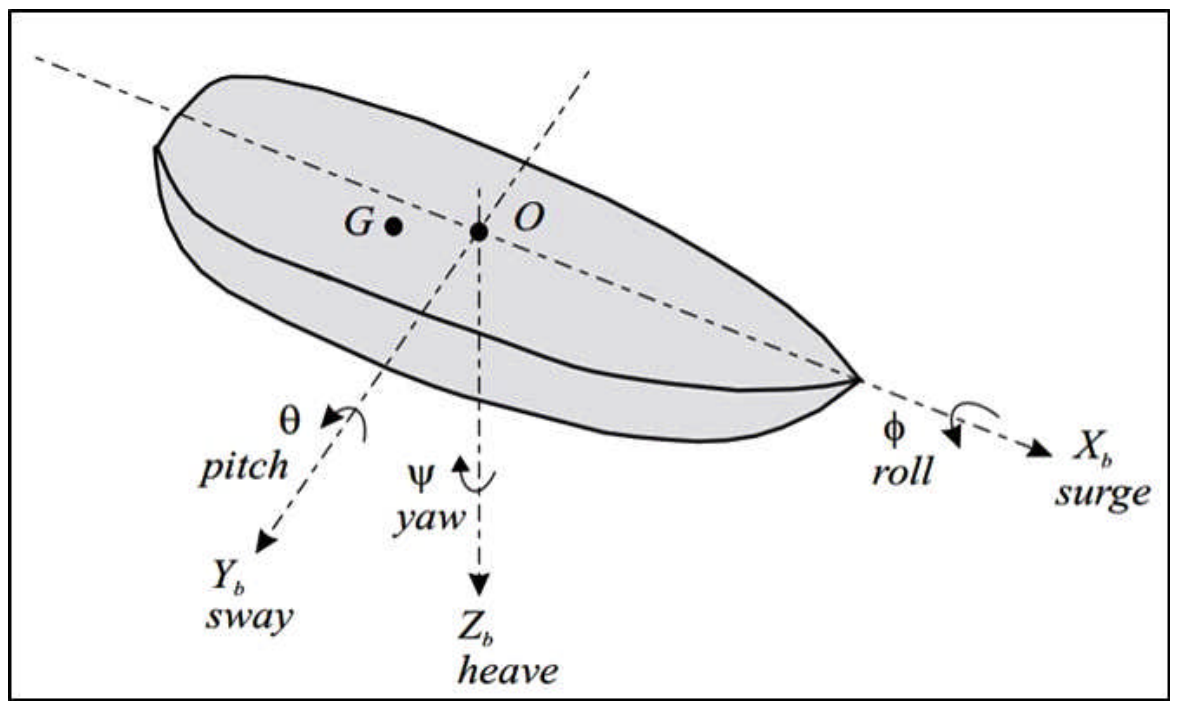

Gambar 4. Enam derajat kebebasan (6DOF) struktur apung.

Jika struktur apung lebih dari satu (multibody) dan saling berpengaruh satu sama lain, maka persamaan gerak (2) dapat dituliskan seperti persamaan (3).

$\sum_{k=1}^{6}\left[\left(m^{N}+m_{a}{ }^{N 1}+\ldots+m_{a} N N\right) \ddot{\zeta}+\left(c^{N 1}+\ldots+c^{N N}\right) \dot{\zeta}+k^{N} \zeta\right]=F^{N} e^{-i w t e t . .(3)}$

Komponen " $N$ ” menunjukkan efek multibody, yang terdiri dari matriks 6 × 6 dari derajat kebebasan. Persamaan tersebut diselesaikan menjadi, Djatmiko, (2012):

$$
\zeta=\frac{F^{N} e^{-i w e t}}{\sqrt{\left.\left[k-\left(m+m_{a}\right) \omega^{2}\right\}^{2}+(c \omega)^{2}\right]}}
$$

dan

$$
\tan \varepsilon=\frac{c \omega}{k-\left(m+m_{a}\right) \omega^{2}}
$$

Persamaan (4) jika dibandingkan dengan amplitudo gelombang reguler maka akan menghasilkan Response
Amplitude Operator (RAO), yaitu perbandingan antara amplitudo gerakan dengan amplitudo gelombang, sebuah instrumen yang menyatakan karakteristik gerakan pada gelombang reguler. RAO inilah yang ditinjau dalam penelitian ini, akibat adanya efek multibody antara FSRU dan LNGC dengan variasi jarak antar keduanya. Persamaan RAO tersebut merupakan bentuk dari frequency domain, dimana harganya bergantung pada frekuensi geombang yang menjadi inputan Djatmiko, (2012). Persamaan (5) menyatakan sudut fase yang terjadi antara gerakan struktur apung dengan gerakan gelombang.

\section{Skenario Pembebanan Gelombang}

Pembebanan gelombang pada struktur apung disimulasikan berpropagasi dari arah headseas (180 deg), quartering seas (135 deg) dan beam seas (90 deg), ditunjukkan pada Gambar 5. Ketiga arah propagasi gelombang ini ditinjau untuk mengetahui efek multibody pada arah pembebanan gelombang. Frekuensi gelombang reguler $(\omega)$ yang diuji berkisar antara $0.2-2.3 \mathrm{rad} / \mathrm{s}$.

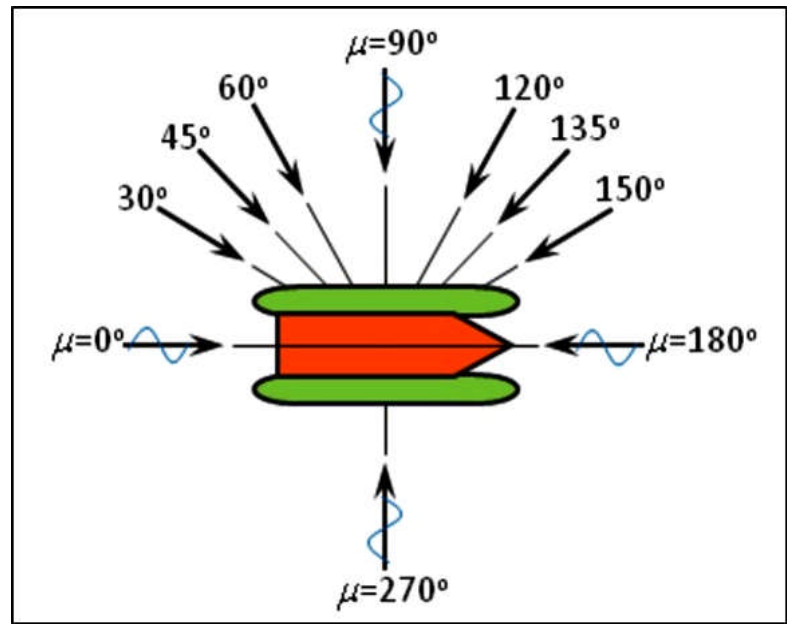

Gambar 5. Konvensi arah propagasi gelombang pada struktur apung (Sumber : [9]). 


\section{HASIL DAN BAHASAN Hasil}

RAO yang dihasilkan dari simulasi numerik dengan pemrograman komputasi difraksi diklasifikan ke dalam 2 bagian, untuk meninjau efek multibody yang terbentuk akibat jarak antara FSRU dan LNGC : a) gerakan vertikal dan b) gerakan horizontal. Gerakan vertikal struktur apung terdiri dari gerakan heave, roll dan pitch, sedangkan gerakan horizontal terdiri dari surge, sway dan yaw.

\section{Efek Multibody pada Gerakan Vertikal Struktur Apung \\ Kondisi Head Seas $\left(\mu=180^{\circ}\right)$}

Efek multibody pada gerakan heave, roll dan pitch akibat gelombang head seas dapat ditinjau pada Gambar 6, 7 dan 8 secara berturut-turut. Warna merah pada grafik menunjukkan RAO LNGC, sedangkan warna biru menunjukkan FSRU. Garis biru penuh merupakan representasi gerakan FSRU free floating, tanpa adanya
LNGC yang tertambat pada FSRU. Sedangkan garis biru putus-putus menunjukkan gerakan FSRU dengan variasi jarak 2, 4, 6 dan $8 \mathrm{~m}$. Terlihat pada ketiga grafik RAO tersebut bahwa propagasi gelombang dari arah head seas ( $\mu=180^{\circ}$ ) tidak menyebabkan dampak signifikan pada variasi jarak antara FSRU dan LNGC, kecuali pada jarak 2 $\mathrm{m}$. Minimumnya efek multibody dikarenakan gelombang langsung melewati celah yang terbentuk antara FSRU dan LNGC, sedangkan pada jarak $2 \mathrm{~m}$, gelombang yang melewati celah terpantulkan pada kedua sisi lambung kapal sehingga terbentuk standing wave.

Efek multibody tampak jelas berdampak pada gerakan roll saat jarak $2 \mathrm{~m}$. RAO puncaknya mencapai $1.9 \mathrm{deg} / \mathrm{m}$ dengan frekuensi naturalnya, $\omega_{n}, 0.6 \mathrm{~s}$, harga ini cukup signifikan dibandingkan dengan gerakan FSRU tanpa LNGC maupun yang berjarak 4,6 dan 8 yang memiliki harga RAO roll $0 \mathrm{deg} / \mathrm{m}$. Selain itu, gerakan roll dengan jarak $2 \mathrm{~m}$ memiliki puncak kedua pada frekuensi $1.1 \mathrm{rad} / \mathrm{s}$ dengan harga $0.2 \mathrm{deg} / \mathrm{m}$.

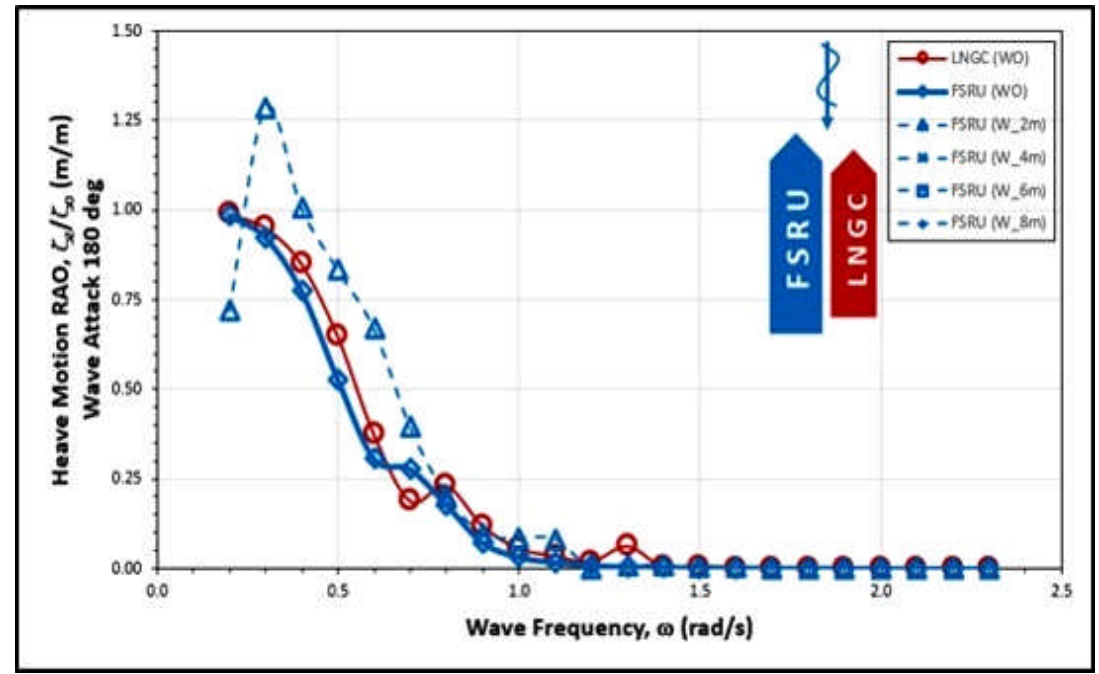

Gambar 6. RAO gerakan heave dengan arah propagasi gelombang head seas.

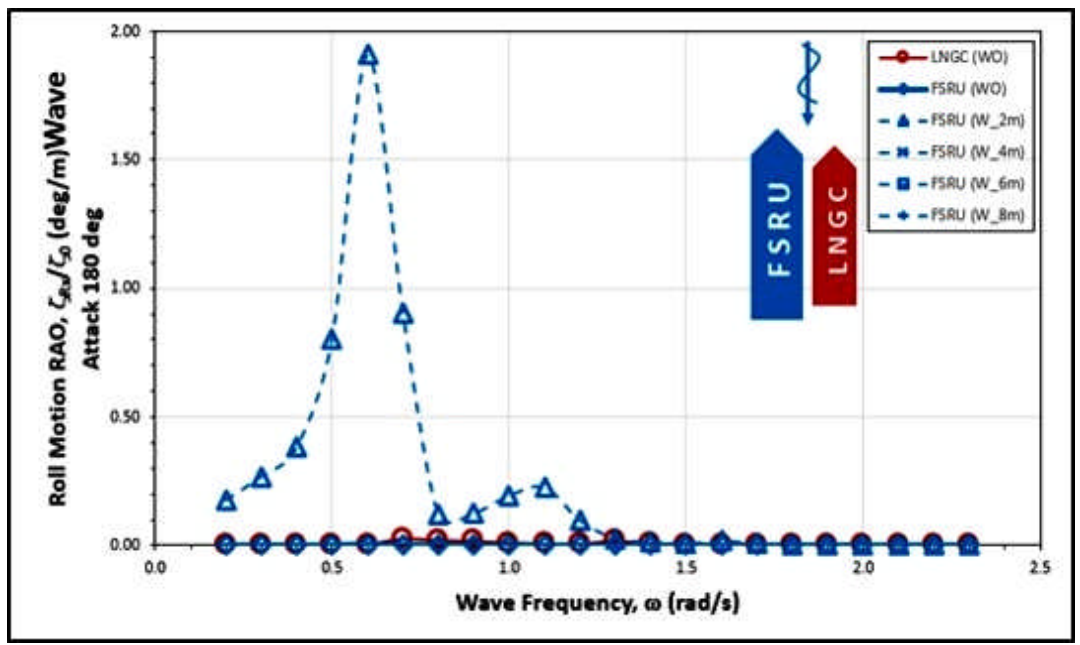

Gambar 7. RAO gerakan roll dengan arah propagasi gelombang head seas. 


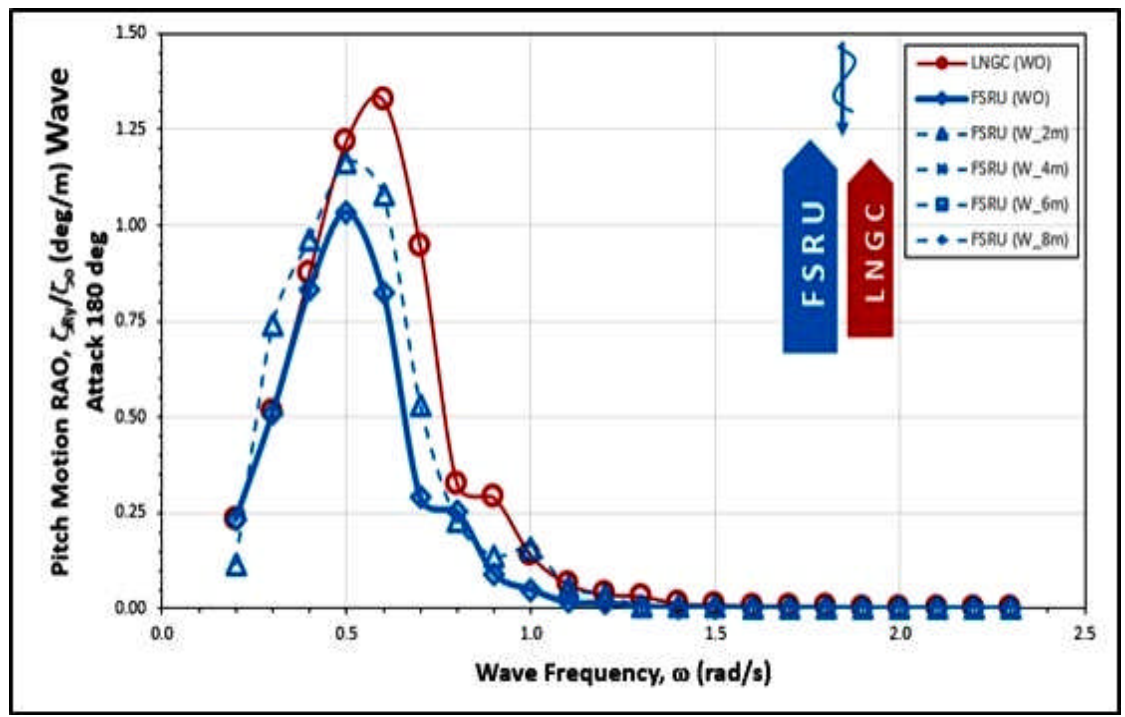

Gambar 8. RAO gerakan pitch dengan arah propagasi gelombang head seas.

\section{Kondisi Quartering Seas $\left(\mu=225^{\circ}\right)$}

RAO gerakan vertikal akibat propagasi gelombang arah miring $\left(\mu=225^{\circ}\right)$ dapat ditunjukkan pada Gambar 9, 10 dan 11 secara berturut-turut. Gerakan heave dapat dilihat pada Gambar 9, berdasarkan gambar tersebut model dengan jarak 4 dan $8 \mathrm{~m}$, memiliki karakteristik gerakan yang identik. Puncak harga RAO heave didapati pada frekuensi $0.5 \mathrm{rad} / \mathrm{s}$ dengan harga puncak mencapai 1.04 $\mathrm{m} / \mathrm{m}$. Puncak RAO pada jarak tersebut bergeser ke frekuensi lebih tinggi, yaitu sebesar $0.3 \mathrm{rad} / \mathrm{s}$ dibandingkan dengan RAO FSRU tanpa LNGC. Sedangkan pada model dengan jarak 2 dan 6 meter, memiliki harga puncak sebesar 1.15 dan $1.46 \mathrm{~m} / \mathrm{m}$, dibandingkan harga puncak FSRU tanpa LNGC yang berharga $1.00 \mathrm{~m} / \mathrm{m}$. Model dengan jarak 2 meter memiliki frekuensi natural pada $0.3 \mathrm{rad} / \mathrm{s}$, sedangkan model dengan jarak $6 \mathrm{~m}$ memiliki frekuensi natural pada $0.5 \mathrm{rad} / \mathrm{s}$.

Gerakan roll pada model dengan jarak 2, 4 dan $8 \mathrm{~m}$ memiliki karakter yang lebih rendah $68 \%$ jika dibandingkan dengan model FSRU tanpa LNGC. Hal ini terjadi karena gaya gelombang teredam oleh keberadaan LNGC. Namun pada model dengan jarak $6 \mathrm{~m}$, puncak RAO sedikit lebih tinggi $5 \%$ dibandingkan dengan FSRU free floating. Frekuensi natural dari keseluruhan model didapati pada frekuensi yang sama, yaitu pada saat $?_{\mathrm{n}}=0.6 \mathrm{rad} / \mathrm{s}$.

RAO gerakan pitch pada model dengan jarak $6 \mathrm{~m}$ juga terlihat memiliki puncak RAO paling tinggi sebesar 2.21 deg.m, jika dibandingkan dengan model lainnya. Efek multibody menaikkan puncaknya hingga sebesar $49 \%$ dari

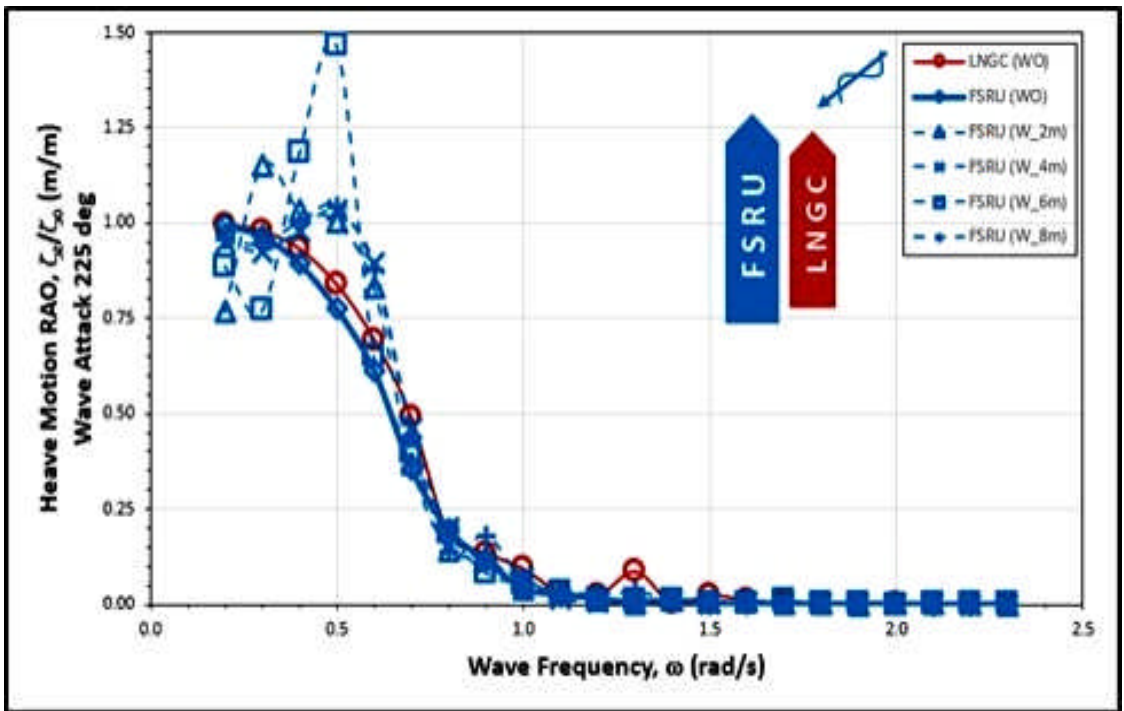

Gambar 9. RAO gerakan heave dengan arah propagasi gelombang quartering seas. 


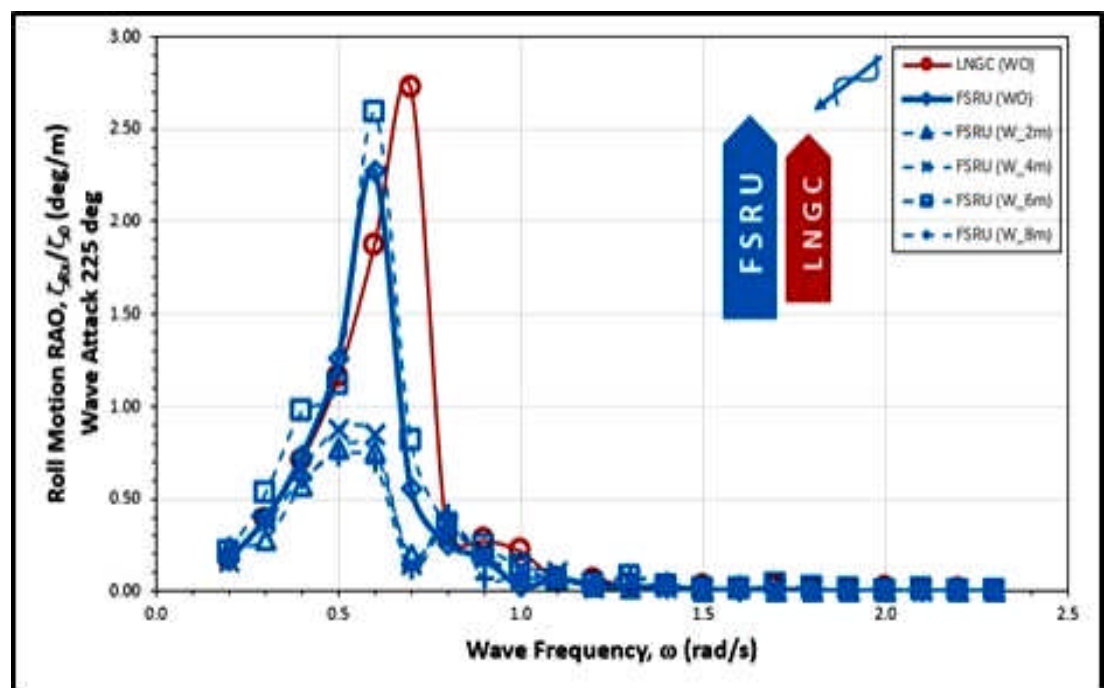

Gambar 10. RAO gerakan roll dengan arah propagasi gelombang quartering seas.

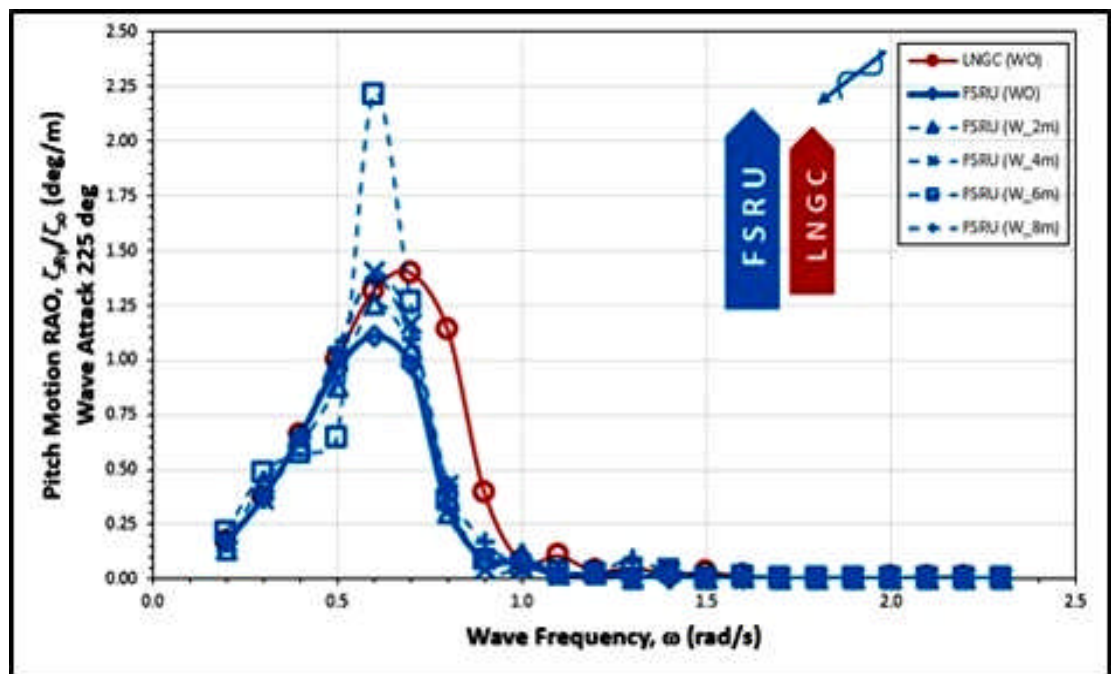

Gambar 11. RAO gerakan pitch dengan arah propagasi gelombang quartering seas.

model FSRU tanpa LNGC.

Kondisi Beam Seas $\left(\mu=270^{\circ}\right)$

Efek multibodyakibat propagasi gelombang arah beam seas $\left(\mu=270^{\circ}\right)$ pada gerakan heave, roll dan pitch disajikan dalam Gambar 12, 13 dan 14 secara berurutan. Frekuensi natural gerakan heave pada Gambar 12 untuk model FSRU dengan jarak 2, 4, 6 dan 8 bergeser ke frekuensi rendah dari model FSRU free floating, yaitu menjadi $\omega=0.6 \mathrm{rad} / \mathrm{s}$. Harga puncak RAO tertinggi didapati pada model dengan jarak $6 \mathrm{~m}$.

Pada gerakan roll frekuensi naturalnya bergeser ke frekuensi lebih tinggi, yaitu $\omega=0.7 \mathrm{rad} / \mathrm{s}$. Hal ini menunjukkan bahwa efek multibody berperan penting dalam menggeser frekuensi natural gerakan dari FSRU tersebut. Puncak RAO untuk tiap-tiap model yang berjarak maupun yang tidak, berkisar antara $4.0-4.6 \mathrm{deg} / \mathrm{m}$.

Efek multibody pada gerakan pitch cukup terlihat jelas, terutama pada model yang memiliki jarak $6 \mathrm{~m}$ sebagaimana yang terlihat pada Gambar 14. Puncak RAO model tersebut dapat mencapai harga $1.1 \mathrm{deg} / \mathrm{m}$. Hal ini menunjukkan walaupun arah gelombang dari arah samping, namun dapat menggerakkan FSRU rotasional terhadap sumbu y (pitch) sebesar $1.1 \mathrm{deg}$ per $1 \mathrm{~m}$ amplitudo gelombang sebagai bentuk akibat dari efek multibody. 


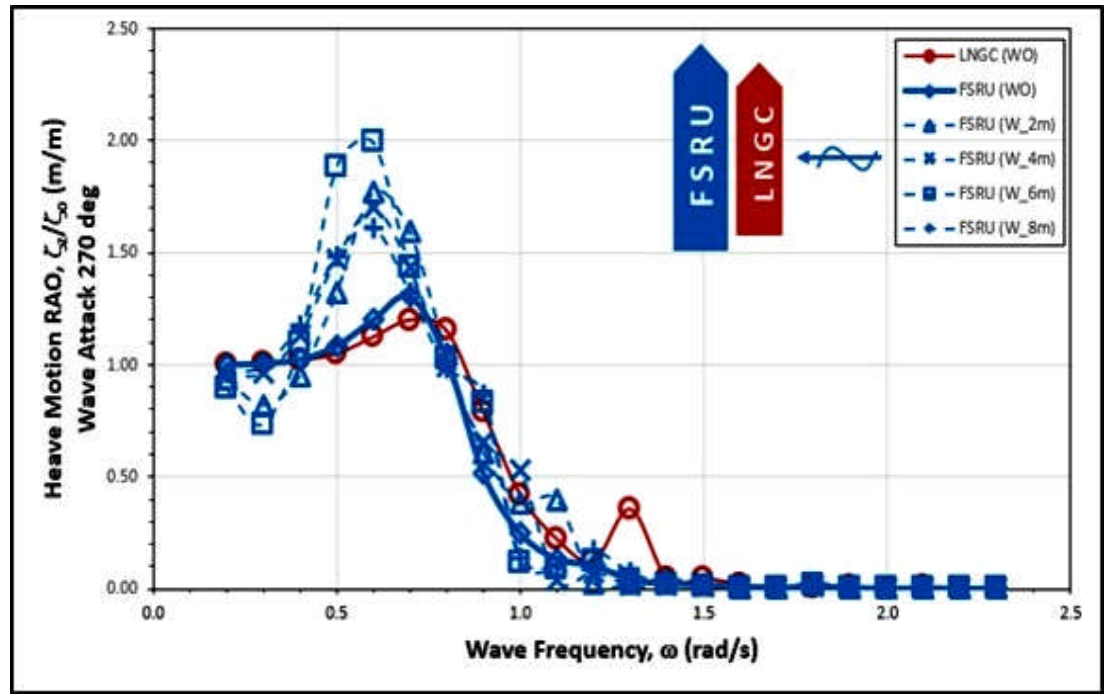

Gambar 12.RAO gerakan heavel dengan arah propagasi gelombang beam seas.

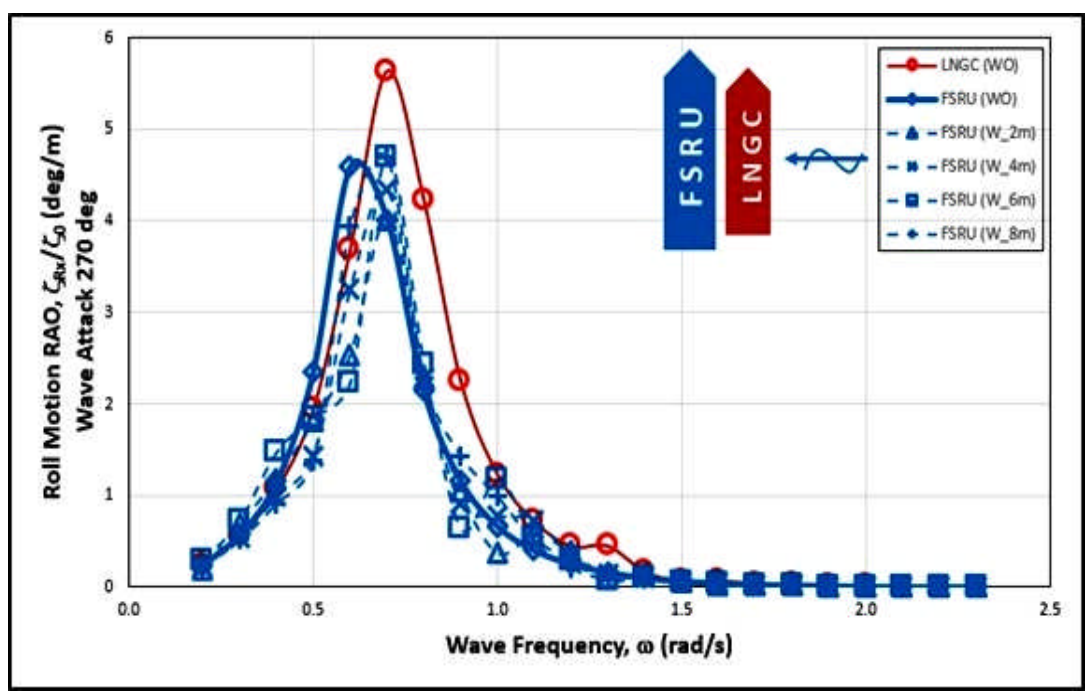

Gambar 13. RAO gerakan roll dengan arah propagasi gelombang beam seas.

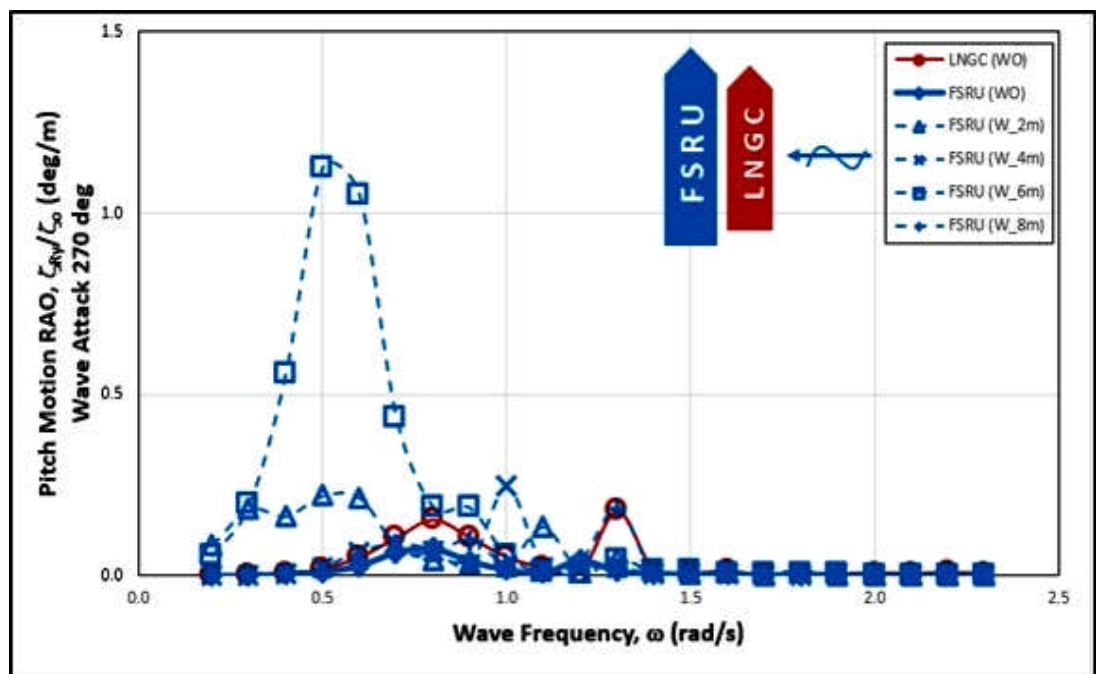

Gambar 14.RAO gerakan pitch dengan arah propagasi gelombang beam seas. 


\section{Efek Multibody pada Gerakan Horizontal Struktur Apung \\ Kondisi Head Seas $\left(\mu=180^{\circ}\right)$}

Efek multibody pada gerakan horizontal, yang terdiri dari surge, sway dan yaw dapat ditunjukkan pada Gambar 15, 16 dan 17 secara berturut-turut. Jika ditinjau secara seksama, efek multibody hanya muncul pada model FSRU dengan jarak $2 \mathrm{~m}$. Hal ini terjadi karena dengan jarak yang relatif kecil menimbulkan terjadinya femomena standing wave antara lambung FSRU dan LNGC, sehingga walaupun propagasi gelombang dari arah haluan kapal, mampu menggerakkan struktur apung pada gerakan sway dam yaw. Harga puncak RAO untuk sway dan yaw mencapai $0.6 \mathrm{~m} / \mathrm{m}$ dan $0.5 \mathrm{deg} / \mathrm{m}$ secara berurutan.

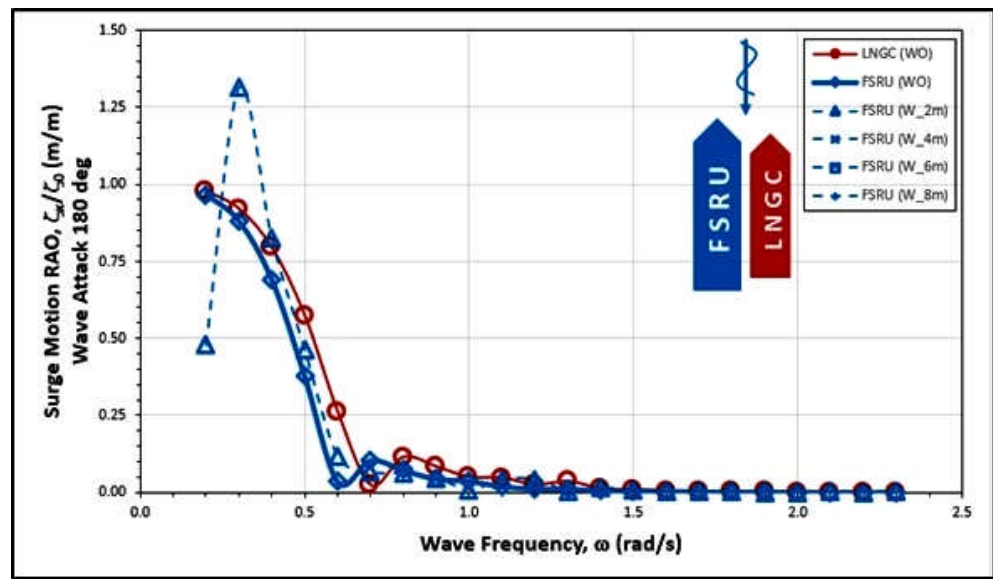

Gambar 15. RAO gerakan surgeldengan arah propagasi gelombang head seas.

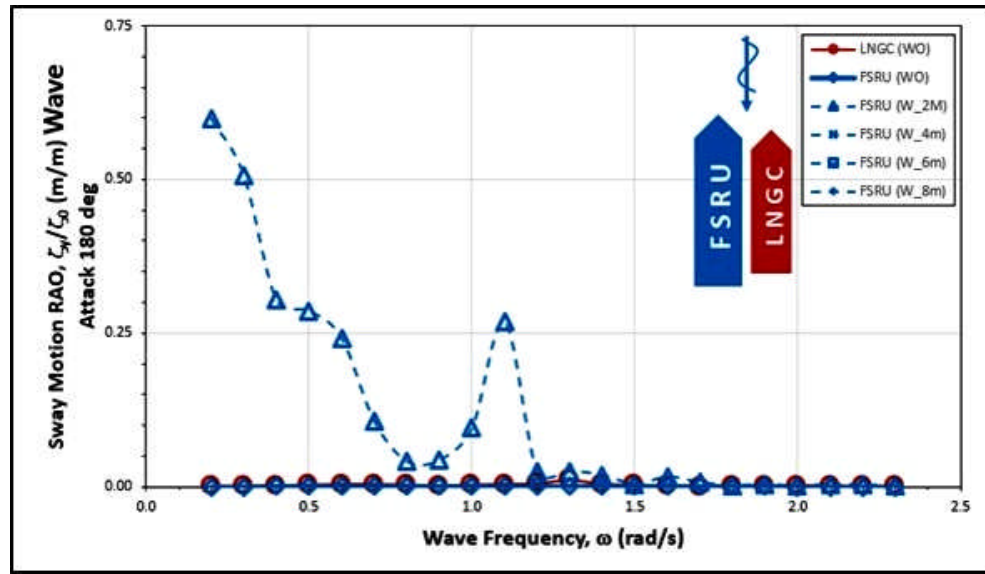

Gambar 16. RAO gerakan sway dengan arah propagasi gelombang head seas.

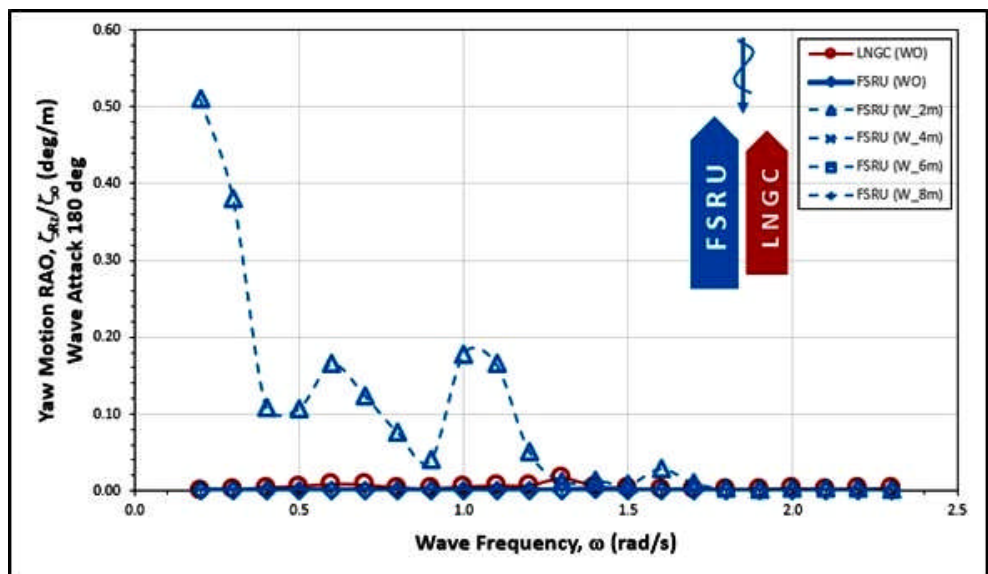

Gambar 17.RAO gerakan yaw dengan arah propagasi gelombang head seas. 


\section{Kondisi Quartering Seas $\left(\mu=225^{\circ}\right)$}

Efek multibody pada gerakan surge, sway dan yaw akibat propagasi gelombang arah seperempat haluan $(\mu$ $=225^{\circ}$ ) dapat dilihat pada Gambar 18, 19 dan 20. Efek multibody pada gerakan surge jarak 4 dan 8 tidak terlalu signifikan dibandingkan dengan FSRU free floating. Dii lain sisi, efek multibody terlihat meredam gerakan sway dan yaw di jarak yang sama, namun pada jarak 2 dan $6 \mathrm{~m}$ terlihat meningkatkan gerakan horizontal pada struktur terapung hingga mencapai 95\% pada gerakan yaw.

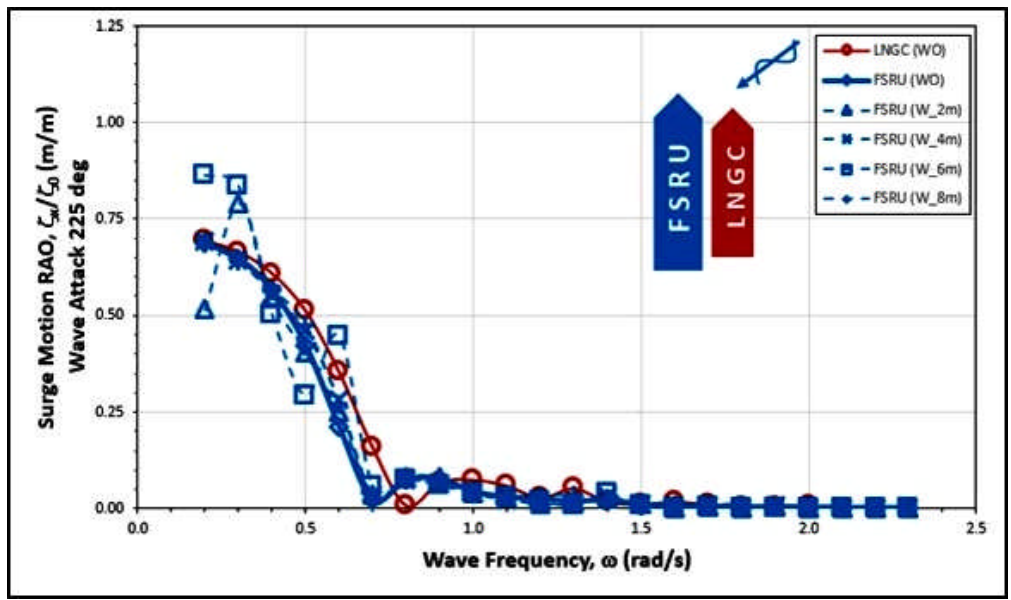

Gambar 18. RAO gerakan surge dengan arah propagasi gelombang quartering seas.

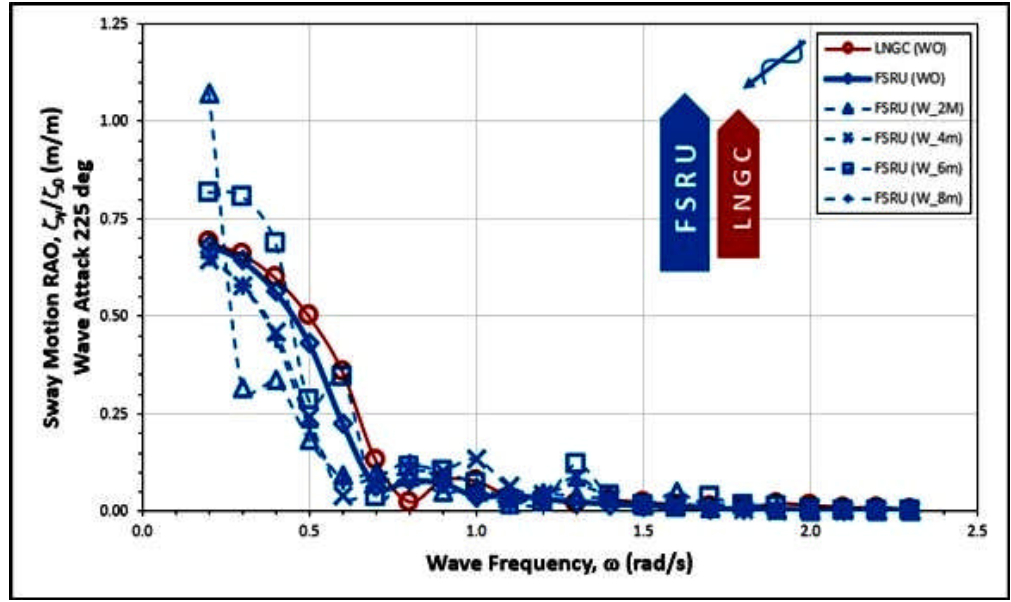

Gambar 19. RAO gerakan sway dengan arah propagasi gelombang quartering seas.

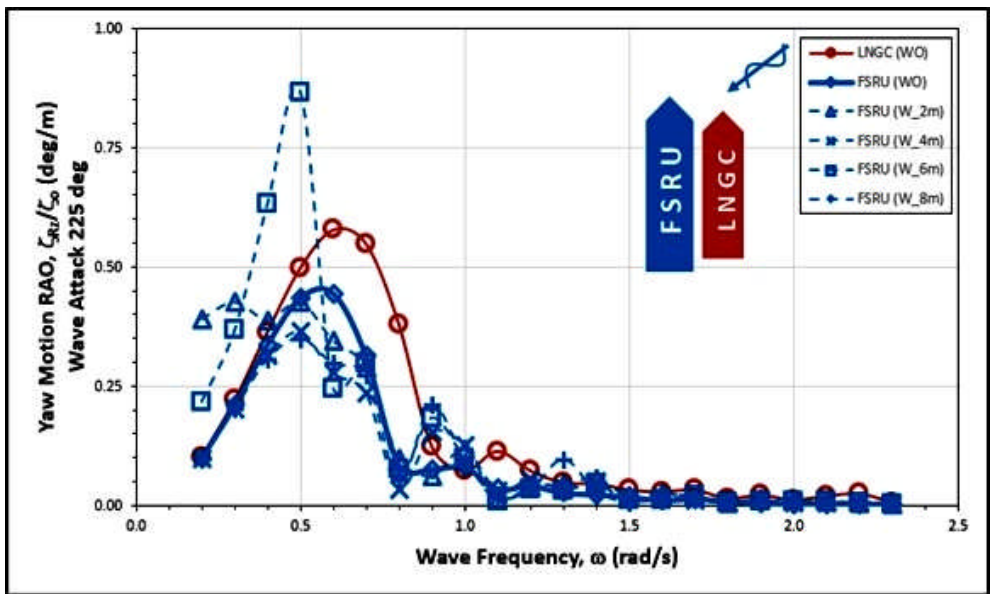

Gambar 20.RAO gerakan yaw dengan arah propagasi gelombang quartering seas. 
Kondisi Beam Seas $\left(\mu=270^{\circ}\right)$

Efek multibody pada gerakan surge, sway dan yaw akibat propagasi geombang dari arah samping ( $\mu=$ $270^{\circ}$ ) dapat dilihat pada Gambar 21, 22 dan 23 secara berurutan. Efek multibody terlihat pada semua gerakan horizontal pada semua variasi jarak. Walaupun efek multibody tidak terlalu signifikan pada jarak 4 dan $8 \mathrm{~m}$, Sedangkan pada jarak 2 dan $6 \mathrm{~m}$ efek multibody terlihat cukup signifikan, beda gerakannya hingga mencapai 23 kali lipat pada gerakan yaw.

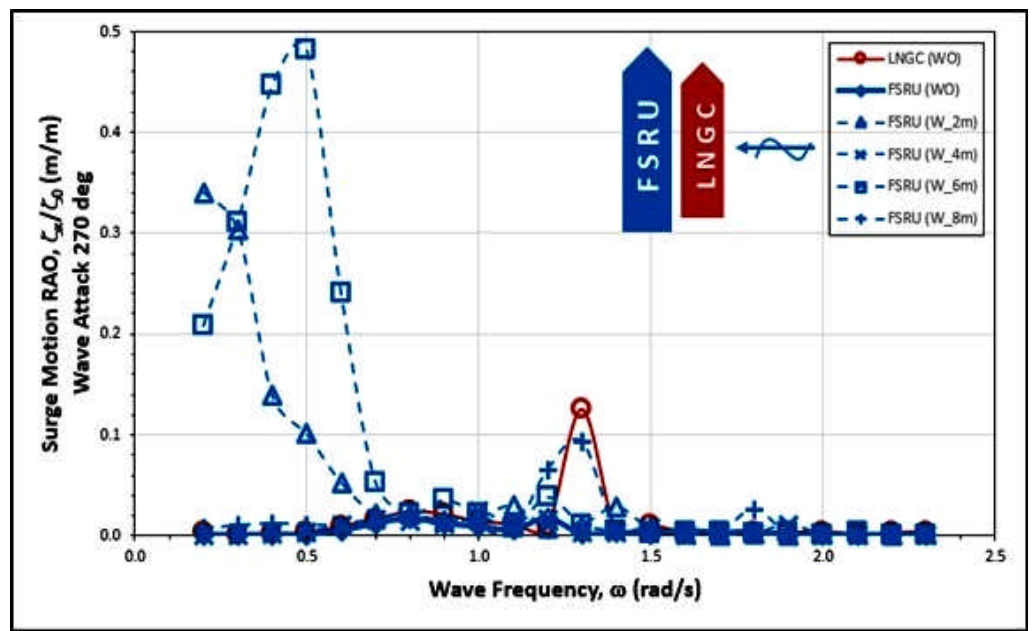

Gambar 21.RAO gerakan surge dengan arah propagasi gelombang beam seas.

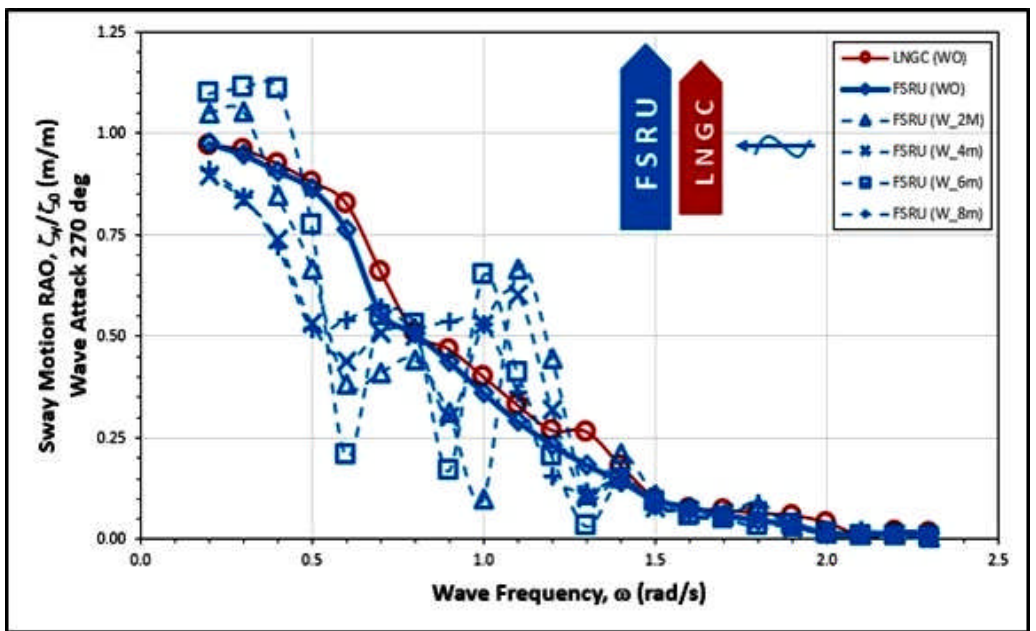

Gambar 22. RAO gerakan swaydengan arah propagasi gelombang beam seas.

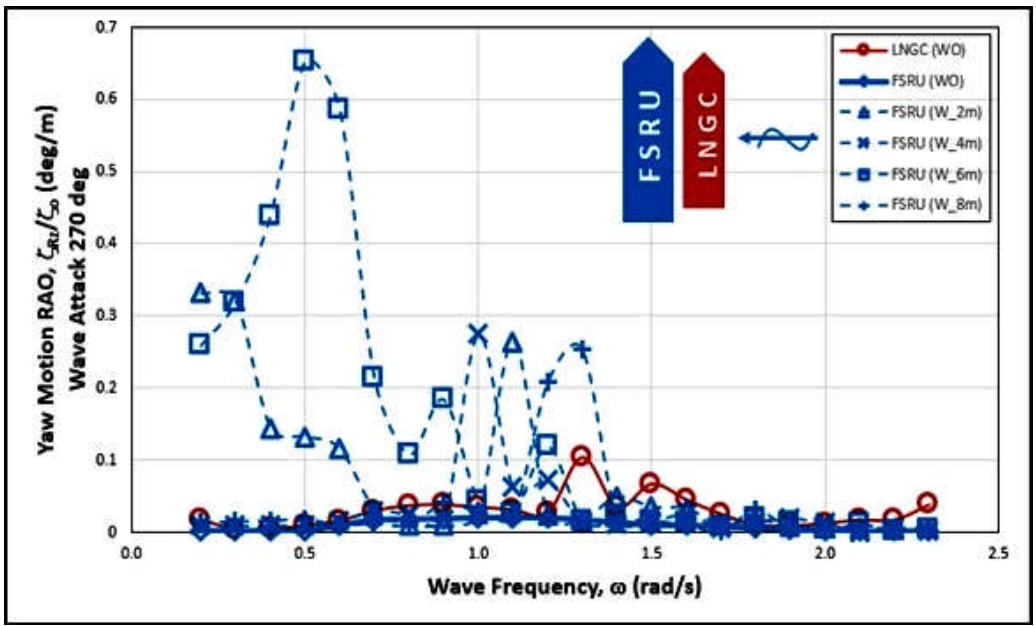

Gambar 23.RAO gerakan yaw dengan arah propagasi gelombang beam seas. 


\section{KESIMPULAN}

Penelitian ini bertujuan mengkaji efek multibodyantara FSRU dan LNGC yang ditambatkan secara side-by-side dengan variasi jarak satu sama lain 2, 4, 6 dan $8 \mathrm{~m}$. Gerakan FSRU ditinjau dalam penelitian ini dengan skenario pemodelan tanpa pengaruh dan terpengaruh keberadaan LNGC. Hal ini penting dilakukan dalam perancangan jetty karena FSRU ditambatkan pada jetty.

Analisis yang digunakan pada penelitian ini adalah analisis dinamis frequency domain dengan RAO 6 gerakan sebagai kriteria yang ditinjau (surge, sway, heave, roll, pitch dan yaw. Pembebanan gelombang pada struktur apung disimulasikan berpropagasi dari arah headseas (180 deg), quartering seas (135 deg) dan beam seas (90 deg). Ketiga arah propagasi gelombang ini ditinjau untuk menginvestigasi efek multibody pada arah pembebanan gelombang. Frekuensi gelombang reguler $(\omega)$ yang diidentifikasi berkisar antara $0.2-2.3 \mathrm{rad} / \mathrm{s}$.

Berdasarkan simulasi numerik yang dihasilkan, didapatkan bahwa efek multibody terlihat pada model FSRU yang berjarak 2, 4, 6 dan $8 \mathrm{~m}$. Efek multibody akibat propagasi gelombang dari arah head seas $\left(\mu=180^{\circ}\right)$ tidak menyebabkan dampak signifikan pada variasi jarak antara FSRU dan LNGC, kecuali pada jarak $2 \mathrm{~m}$. Minimumnya efek multibody dikarenakan gelombang langsung melewati celah yang terbentuk antara FSRU dan LNGC, sedangkan pada jarak $2 \mathrm{~m}$, gelombang yang melewati celah terpantulkan pada kedua sisi lambung kapal sehingga terbentuk fenomena standing wave.

Pada gelombang yang berpropagasi arah seperempat haluan ( $\mu=225^{\circ}$ ) dan arah samping ( $\mu=270^{\circ}$ ) juga terlihat adanya efek multibody pada variasi jarak antar FSRU dan LNGC. Pada model dengan jarak 4 dan $8 \mathrm{~m}$, karakter RAO cenderung lebih rendah atau sama dengan RAO pada model FSRU free floating. Namun pada jarak 2 dan $6 \mathrm{~m}$, karakter RAO lebih tinggi dari dari RAO FSRU free floating. Selain menaikkan dan menurunkan harga RAO gerakan, efek multibodyjuga menggeser frekuensi natural $\left(\omega_{n}\right)$ struktur bangunan apung dengan beda 0.1 $0.3 \mathrm{rad} / \mathrm{s}$. Hal ini penting diketahui karena posisi frekuensi natural dapat memicu magnifikasi gerakan jika terjadi resonansi.

\section{DAFTAR PUSTAKA}

Gus. (2019). Indonesia Ternyata Masuk 5 Besar Eksportir LNG Dunia. https://www.cnbcindonesia.com/news/ 20190306094058-4-59127/indonesia-ternyatamasuk-5-besar-eksportir-lng-dunia. 28-02-2019. 09.34 WITA

Siswanto., Djoko. (2018). Laporan Tahunan Capaian Pembangunan 2018 : Pemanfaatan Gas Bumi untuk Energi Berkeadilan. Direktorat Jenderal Minyak dan Gas Bumi, Kementerian Energi dan Sumber Daya Mineral.

OCIMF. (2008). Mooring Equipment Guidelines. United Kingdom.

Kim, Y.B. (2003). "Dynamic Analysis Of Multiple-Body Floating Platformscoupled With Mooring Lines And Risers". Dissertation of PhD Ocean Engineering. Texas A\&M University.

Bunnik, T. (2009). “Hydrodynamic Analysis for Side By Side Offloading". Proceeding of the 19th International Offshore and Polar Engineering Conference, ISOPE, Osaka.

Perwitasari, R.P. (2010). "Hydrodynamic Interaction and Mooring Analysis For Offloading Between FPSO and LNG Shuttle Tanker". Master Thesis of Departement Marine Technology, Norwegian University of Science and Technology, Trondheim.

Ziyan, M. (2013). "Analisis Operabilitas FSRU Akibat Beban Lingkungan Berbasis Ranah Waktu”. Tugas Akhir Jurusan Teknik Kelautan. Institut Teknologi Sepuluh Nopember, Surabaya.

Wibowo, Y.A. (2014). "Horizontal Distance Effect Analysis In Side by side Configuration between FSRU And LNGC due to Motion Characteristic of Multibody and Coupling Line Tension”. Undergraduate Theses of Ocean Engineering. Sepuluh Nopember Institute of Technology, Surabaya.

Djatmiko, E.B. (2012). Perilaku dan Operabilitas Bangunan Laut di Atas Gelombang Acak. Surabaya : ITS Press. 